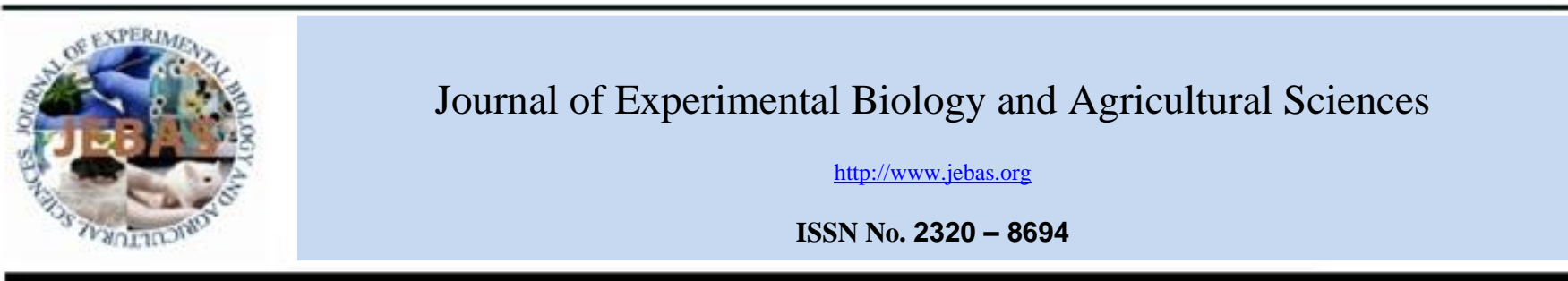

\title{
CHARACTERISTICS AND MECHANISM OF POTENTIAL PROBIOTICS WITH SPECIAL REFERENCE TO LACTIC ACID BACTERIA FROM TRADITIONAL FERMENTED FISH PRODUCTS: A REVIEW
}

\section{Soibam Ngasotter ${ }^{1 *}(\mathbb{D})$, David Waikhom ${ }^{1}$ (D), Sanjeev Sharma ${ }^{2}$ (D), Maibam Malemngamba Meitei ${ }^{2}(\mathbb{D})$, Yumnam Abungcha Mangang ${ }^{2}(\mathbb{D})$, Suraj Kumar Irungbam $^{2}(\mathbb{D}$, Bhuneshwar ${ }^{1}$ (D), Manoharmayum Shaya $\operatorname{Devi}^{3}$ (D), Asem Sanjit Singh ${ }^{1}(\mathbb{C}$}

${ }^{1}$ ICAR-Central Institute of Fisheries Education (CIFE), Mumbai, 400061, India.

${ }^{2}$ College of Fisheries, Central Agricultural University (Imphal), Tripura, 799210, India.

${ }^{3}$ ICAR-Central Inland Fisheries Research Institute (CIFRI), Barrackpore, 743101, India.

Received - January 25, 2021; Revision - April 17, 2021; Accepted - June 03, 2021

Available Online - June 25, 2021

DOI: http://dx.doi.org/10.18006/2021.9(3).263.275

\section{KEYWORDS}

Fermented fish products

Lactic acid bacteria

Probiotic properties

Probiotic mechanism

Probiotic characteristics

\begin{abstract}
Lactic acid bacteria (LAB) are widely used in the food industry due to their probiotic properties and fermentation activities. Traditional fermented fish products are dominated by a diverse variety of lactic acid bacteria with significant probiotic characteristics. Several in vitro and in vivo studies on lactic acid bacteria from fermented fish products have confirmed LAB strains to possess characteristics to be considered as probiotics that contribute to positive health benefits to the host and are generally regarded as safe (GRAS). This paper presents a review of the characteristics of the LAB strain that is considered as a probiotic. It also presents an overview of the probiotics mechanism of action and specifically highlights the LAB species with potential probiotic characteristics isolated from traditional fermented fish products.
\end{abstract}

* Corresponding author

E-mail: ngasotter@gmail.com (Soibam Ngasotter)

Peer review under responsibility of Journal of Experimental Biology and Agricultural Sciences.

Production and Hosting by Horizon Publisher India [HPI] (http://www.horizonpublisherindia.in/).

All rights reserved.
All the articles published by Journal of Experimental Biology and Agricultural Sciences are licensed under a Creative Commons Attribution-NonCommercial 4.0 International License Based on a work at www.jebas.org.

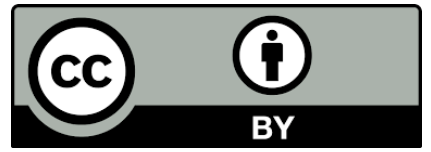




\section{Introduction}

Lactic acid bacteria (LAB) are a group of Gram-positive, catalasenegative, oxidase-negative, acid-tolerant, non-spore forming, fermentative bacteria that grow anaerobically and are traditionally applied in the conservation of a variety of fermented food products (Mulaw et al., 2019). For use as functional food materials and probiotics, LAB have been isolated from a variety of environments and fermented foods (Foligné et al., 2013; Solieri et al., 2014; Ngasotter et al., 2020). LAB have been consumed in terms of diverse food supplements and widely used as a food preservation for thousands of years due to their probiotic properties and fermentation activities and are generally regarded as safe (GRAS) (Haghshenas et al., 2014; Mathur et al., 2020). Probiotics can be defined as "a live microbial food supplement that benefits the host by improving the intestinal microbial balance" and more broadly, as live microorganisms that exert positive health benefits (Fuller, 1989; FAO/WHO, 2002; Chugh \& Kamal-Eldin, 2020). The physicochemical conditions that influence the composition of the intestinal microbiota include intestinal $\mathrm{pH}$, motility, redox potential, nutrient availability, host secretions (e.g. digestive enzymes, hydrochloric acid, bile, and mucus), and the presence of an intact ileocecal valve (Booijink et al., 2007). Thus, probiotics are capable of surviving these conditions and colonize the gastrointestinal (GI) tract to provide probiotic health effects. Probiotics microorganisms benefit the host by changing the equilibrium of intestinal microflora, inducing immunity, improving digestion, reducing cholesterol, alleviate lactose intolerance and increase resistance towards several intestinal infections (Helland et al., 2004; Parvez et al., 2006). Certain properties relevant to probiotic action are resistance to acid, bile salt tolerance, adhesive properties, antibacterial activity, and antibiotic susceptibility. These probiotic properties are strain-specific and among these some specific strains of Lactobacillus, Bifidobacterium, and Propionibacterium have already been introduced as probiotics in food products due to their health-promoting effects (Collado et al., 2008).

Food fermentation is a method of preservation and one of the oldest food processing techniques. It can be achieved naturally (without the use of starter cultures) or under controlled conditions (with the use of starter cultures). The ingestion of bacteria in the form of fermented foods could beneficially affect the normal gut flora (Bell et al., 2018). These properties consist of the beneficial effects that probiotics exert on the microbial ecology of the host. Fish fermentation has been practiced since ages and has many benefits and because of this, these could be used as a low-cost convenient technique for preserving fish muscle, improving its organoleptic qualities and nutritional value, and/or digestibility of the raw material. Today, fermented fish products are limited, especially for the east and south-east Asian countries, though some products are produced elsewhere and exported from Oriental to European and North American countries (Adams, 2009). Fermented fish products are reported to be dominated by a diverse variety of lactic acid bacteria (Ngasotter et al., 2020). The primary role of LAB in many fermented fish products is to ferment carbohydrates and reduce $\mathrm{pH}$. Further, the combination of low $\mathrm{pH}$ (below 4.5) and organic acids (mainly lactic acid) is the main preservation factor in the various fish products (Kose \& Hall, 2011). Traditionally fermented fish products are dominated by LAB and are known for their probiotic values (Singh et al., 2018; Ngasotter et al., 2020). Although the molecular mechanisms of probiotics have not been clarified, their regulation of the intestinal microbiota, antimicrobial activity, improvement of the epithelial barrier function, and reduction of the intestinal inflammation is already well established. This review paper provides information on different properties that a LAB strain must possess to be considered as a probiotic. It also provides an overview of the mechanism of action of probiotics and specifically highlights the LAB species with probiotic properties isolated from traditional fermented fish products.

\section{Probiotic characteristics}

A LAB strain must possess certain characteristics to be classified as a probiotic, such as resistance to gastric acidity (low $\mathrm{pH}$ ), bile salt resistance, adherence properties such as mucus adhesion and/or human epithelial cell and cell line adhesion, ability to minimize pathogen adhesion to surfaces, antimicrobial activity against potentially pathogenic bacteria or fungi, bile salt hydrolase activity, enhancing the viability of probiotics and antibiotic sensitivity. Microorganisms commonly used as probiotics are LAB and Bifidobacterium, although other bacteria and certain yeasts are also used (Didari et al., 2014). The properties of probiotics are strain-specific and therefore, one strain differs from other strain in terms of probiotic properties.

Certain LAB strains can resist the extreme acidity (low $\mathrm{pH}$ ) of the GI tract or bile salts of the small intestine (Mbye et al., 2020), exhibiting resistance to acidity as a strain-dependent process. Since the beneficial effects of probiotics are mainly centralized in the GI tract, probiotics should exhibit good surface hydrophobicity and aggregation properties to adhere and colonize in the GI tract. Bacterial adhesion depends on the nonspecific physico-chemical bonding of two surfaces. The surface hydrophobicity determines the chemical and physical properties of the cell surface of bacteria (Kotzamanidis et al., 2010). Other functional properties of probiotics include hypocholesterolemic activity by lowering plasma cholesterol (Ishimwe et al., 2015), preventing and treating diarrhea (FAO/WHO, 2002; Mekonnen et al., 2020), and altering the immune system (La Fata et al., 2018). 


\subsection{Low pH survival}

The tolerance to an acidic condition of the GI tract is an important criterion for being a probiotic bacterium. Gastric juice in the stomach of the host is a biological barrier where the $\mathrm{pH}$ is between 1.5 and 3.0 and the probiotic bacterium must survive and grow in this acidic environment and subsequently colonize the GI tract. Acid tolerance of bacteria is crucial not only for withstanding gastric stresses but also enables the strain to survive for longer periods in high acid carrier foods, such as yogurt, without a reduction in their number (Wang et al., 2010). In general, LAB can induce an acid tolerance response (ATR) under acidic stress and results in $\mathrm{pH}$ homeostasis and repair process, which makes them resistant to an acidic condition in response to low $\mathrm{pH}$ (Wang et al., 2018). Certain LAB strains can resist the extremely low $\mathrm{pH}$ conditions of the GI tract or bile salts of the small intestine (Mbye et al., 2020), exhibiting resistance to acidity as a strain-dependent process.

\subsection{Bile salt tolerance}

Besides the extremely low $\mathrm{pH}$ conditions of the stomach, the probiotic microorganisms have to defend against the bile salt of the GI tract. Hence, bile salt tolerance is considered to be one of the important properties required for its survival and as a consequence of the probiotic activity. Bile salts are toxic to living cells, so bile salt tolerance is one of the most important characteristics for LAB to survive in the small intestine (Succi et al., 2005; Patel et al., 2010). Bile salts are another biological barrier of the GI tract and may damage bacterial cell membranes by disrupting its lipids and fatty acids (Urdaneta \& Casadesús, 2017). In the human body, the physiological concentration of bile salts in the small intestine is between $0.2 \%$ and $2.0 \%$ (Gunn, 2000). Bile plays a fundamental role in the gut environment, and it acts as bio-surfactants that help in digestion and nutrients absorption as well as control the transport of soluble lipid. Bile salts concentrations determine the primary strength of its inhibitory effects (Succi et al., 2005). It is considered that bile salt causes the increase in permeability of bacterial cell membranes, as the membranes are composed of lipids and fatty acids. LAB such as Lactobacillus sp. can hydrolyze bile salts through the secretion of bile salt hydrolase (BSH), making them able to tolerate bile (Prete et al., 2020). Additionally, the thick defensive layer of exocellular polysaccharides induces bacteria towards bile resistance (Boke et al., 2010). The inhibition of common intestinal bacteria has been related to the presence of deconjugated bile acids rather than conjugated ones (Grill et al., 2000). The ability to hydrolyze bile salts can help the microorganism to sustain the balance of the gut microflora (Horackova et al., 2020). BSH activity is also correlated to a decrease in cholesterol levels in humans (Hernández-Gómez et al., 2021).

\subsection{Adherence properties}

Adherence is another crucial characteristic that a LAB species must have to be considered as probiotic bacteria (Bubnov et al., 2018). The ability to adhere can give information about the possibility of probiotics to colonize in the GI tract of the host which may modulate the host immune system. Adherence to intestinal epithelial cells and the mucosal surface of the host is crucial properties of probiotics that contributes a decisive part in the removal of other pathogens. Further, it was reported that hydrophobicity (Duary et al., 2011) and aggregation ability (Collado et al., 2008; Jankovic et al., 2012) are correlated to cell adherence properties. The probiotics should exhibit good surface hydrophobicity and aggregation properties to adhere to and colonize in the GI tract. Bacterial adhesion depends on the nonspecific physico-chemical bonding of two surfaces. The surface hydrophobicity determines the chemical and physical properties of the bacterial cell surface (Kotzamanidis et al., 2010).

\subsubsection{Auto-aggregation}

The auto-aggregation ability of the probiotics is related to cell adherence properties. Auto-aggregation property may contribute an effective role in the prevention of biofilm formation of pathogenic microorganisms and the elimination of these pathogens from the host GI tract (Monteagudo-Mera et al., 2019). Thus increased autoaggregation plays a vital role in the adhesion of bacterial cells to the intestinal epithelium and it increases the chance of bacterial maintenance in the GI tract. Bacterial aggregation between cells of the same strain (auto-aggregation) or between different strains (coaggregation) is of considerable importance in several ecological niches, especially in the human gut where probiotics are active (Nikolic et al., 2010). The auto-aggregation ability is one of the crucial factors that determine the ability of the probiotic strain to adhere to the oral cavity, GI tract, and urogenital tract, and coaggregation ability helps to form a barrier that prevents colonization of pathogens. Lactobacillus sp. with aggregation ability and hydrophobic cell surface could have more chance for adhesion to intestinal cells (Martín et al., 2005).

\subsubsection{Cell surface hydrophobicity}

Cell surface hydrophobicity is another crucial factor that may contribute to the adhesion of bacterial cells to host intestinal epithelial cells (Krausova et al., 2019). This property could indicate an advantage and importance for bacterial maintenance in the human GI tract (Dlamini et al., 2019). Thus, cell surface hydrophobicity is an important characteristic that helps the probiotics to colonize and modulate the host immune system.

The hydrophobic properties of the probiotic bacterial surfaces are a major determinant in the adhesion of probiotic bacteria and the formation of biofilms by bacteria on animate and inanimate 
surfaces (Doyle \& Rosenberg, 1990). Hydrophobicity is likely due to a complex interplay between positively-charged, negativelycharged, hydrophobic, and hydrophilic components on the surface of the bacteria. Relative hydrophobicity of bacterial cells can be determined by several methods, such as microbial adherence to hydrocarbons (MATH), hydrophobic interaction chromatography (HIC), aggregation in the presence of different salt solutions, and adhesion to nitrocellulose filters (Donlon \& Colleran, 1993).

\subsubsection{Biofilm formation}

Biofilm formation helps probiotic bacteria to colonize in the GI tract of the host and subsequent metabolic processes as well as competing with non-adherent organisms for nutrients (Gómez et al., 2016). The probiotic bacteria can co-aggregate even with other bacteria that are genetically different (Malik et al., 2003). Bacteria having the ability to co-aggregate are also able to form biofilm and adhere to the mucosal layer of the host and thus inhibit the functions of the pathogenic bacteria (Collado et al., 2007).

\subsection{Antimicrobial activity}

Probiotic bacteria should have good antimicrobial properties against other microorganisms, particularly to the pathogens that colonize the GI tract system like Escherichia coli, Staphylococcus aureus, Salmonella typhi, etc. They are occasionally found as foodborne microorganisms that might cause gastroenteritis in humans. Antimicrobial activity can be achieved by the production of antimicrobial substances produced by probiotics such as bacteriocins, conjugated bile salts, organic acids such as lactic acid, hydrogen peroxide, etc (Reis et al., 2012). The production of organic acid and hydrogen peroxide by Lactobacillus sp. was reported to inhibit both Gram-positive and Gram-negative bacteria, whereas bacteriocin affects only the growth of Gram-positive bacteria (Spelhaug \& Harlander, 1989). Antimicrobial components produced by LAB can inhibit the growth of pathogenic and spoilage bacteria (Ren et al., 2018). LAB's natural antimicrobial compounds have long been used as chemotherapeutic agents to control the growth of pathogenic microorganisms (Liasi et al., 2009). Although LAB produces antimicrobial compounds, they are included as safe microorganisms when added to food because it is not toxic and does not produce a toxin, so-called food-grade microorganisms, and are designated as "GRAS."

\subsection{Antibiotic sensitivity}

The antibiotic susceptibility pattern of the isolate represents its safe consumption without any health risk. Probiotic bacteria may serve as a host of antibiotic resistance genes, which can be transferred to pathogenic bacteria and other microorganisms. Although LAB are "GRAS," it has been shown that genes coding for antibiotics resistance can be transferred among bacteria of different genera and thus to human commensal microflora and pathogens, temporarily residing in the hosts (Adimpong et al., 2012). Few LAB has shown high resistivity to antibiotics due to the presence of antibiotic resistance genes. Antimicrobial resistance genes can be transferred to pathogenic microorganisms through LAB from fermented food products, either through the food web or, more importantly, through the GI tract of humans and animals (Verraes et al., 2013). The transfer of resistance genes between strains is a necessary mechanism for the LAB to adapt and survive in a specific environment (Herreros et al., 2005). Therefore, before a strain of $\mathrm{LAB}$ can be used as a probiotic, it must be tested for antibiotic resistance to ensure that it is safe to use.

\section{Mechanism of action of probiotics}

The mechanisms by which probiotics exert their beneficial effects on the host include the reduction of gastrointestinal $\mathrm{pH}$, competition with pathogens for nutritional sources and adhesion sites, secretion of antimicrobial substances, toxin inactivation, and immune stimulation (Figure 1). Mechanism of probiotic action can be classified into three types: (i) Immune system modulation, (ii) direct effects on other microorganisms, and (iii) antitoxin effects (Oelschlaeger, 2010).

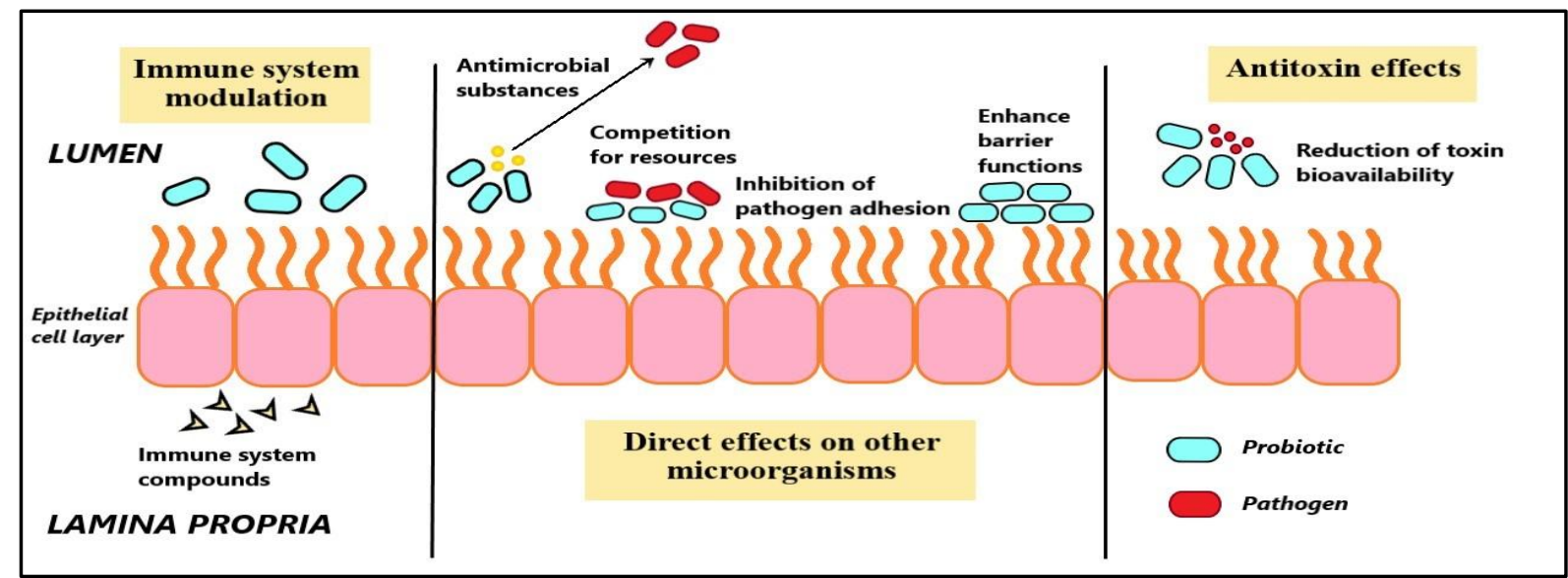

Figure 1 Mechanism of action of probiotics inside the human host epithelial cells

Journal of Experimental Biology and Agricultural Sciences http://www.jebas.org 


\subsection{Immune system modulation}

Probiotics can modulate the host's immune system by producing products like metabolites, cell wall components, and DNA. Immune modulatory effects might even be accomplished with dead probiotic bacteria or just probiotics-derived components like DNA or peptidoglycan fragments (Piqué et al., 2019). Probiotic products are recognized by host cells sensitive to these since they are equipped with recognition receptors. The main target cells of probiotics in the host are gut epithelial and gut-associated immune cells. Probiotic adhesion to the host (epithelial) cells can trigger a signalling cascade that leads to immune modulation. Alternatively, the release of soluble components can also trigger signaling cascades in immune cells or in epithelial cells which may subsequently affect immune cells (Oelschlaeger, 2010).

\subsection{Direct effects on other microorganisms}

\subsubsection{Antimicrobial substances produced by probiotics}

\subsubsection{Bacteriocins}

Low-molecular-weight substances such as organic acids, mostly lactic acid in the case of LAB have an inhibitory effect on pathogens. Bacteriocins are classified into low-molecular-weight bacteriocins (LMWBs) and high-molecular-weight bacteriocins (HMWBs). The LMWB are antimicrobial peptides. LMWB can be grouped into three classes: (class I) lantibiotics, post-translationally modified peptides harboring unusual amino acids such as lanthionine, (class II) heat-stable non-lantibiotics, (class IV) cyclic antimicrobial peptides (Maqueda et al., 2008). Class III bacteriocins come under HMWB. Besides LMWB, probiotics also produce certain antibiotics. The production of the antibiotic reuterin (3-hydroxypropionaldehyde) by Lactobacillus reuteri has been reported. Reuterin is a broad-spectrum antibiotic that is effective against Gram-positive and Gram-negative bacteria as well as against fungi, yeast, viruses, and protozoa (Cleusix et al., 2008). Probiotics also produce microcins, which are very small bacteriocins composed of few peptides with a narrow window of activity (Sassone-Corsi et al., 2016).

\subsubsection{Deconjugated bile acids}

Probiotic bacteria can produce deconjugated bile acids which are derivatives of bile salts. Deconjugated bile acids show a stronger antimicrobial activity compared to the bile salts secreted by the host organism (Oelschlaeger, 2010).

\subsubsection{Competition for limiting resources}

Probiotic microorganisms compete with other microorganisms for limited resources in the host. For example, iron is a limited substance in the host. For almost all bacteria, iron is an essential element except for Lactobacilli sp. They do not need iron in their natural habitat (Weinberg, 1997). This might be a vital advantage in competition with other microorganisms that depend on iron. Nevertheless, L. acidophilus and $L$. delbrueckii can bind ferric hydroxide at their cellular surface, making it unavailable to pathogenic microorganisms (Elli et al., 2000).

\subsubsection{Anti-adhesive effects}

Probiotic bacteria can adhere to epithelial cells in cell culture assays, thereby blocking off other microorganisms' adherence. It is assumed that this mechanism is critical for the probiotic effect in the host. The anti-adhesive effect is probably the result of competition between probiotics and other microorganisms for the same receptor or the induction by probiotics of (increased) mucin production (Nair et al., 2017). Besides competitive exclusion, i.e. competition for the same receptor by probiotics and other microorganisms, other modes of anti-adhesiveness could be the degradation of carbohydrate receptors by secreted proteins, production of receptor analogs, establishing a biofilm, and the induction of biosurfactants (Oelschlaeger, 2010).

\subsubsection{Anti-invasive effects}

The invasion of pathogens into the epithelial cells of the host is an essential property for the total pathogenicity of many gut pathogens. Some probiotics can specifically interfere with bacterial host cell invasion (Nair et al., 2017). Few studies have reported that certain secreted factors of some probiotic Lactobacillus sp. and Bifidobacterium bifidum are interfering with the invasion of host epithelial cells by Salmonella typhimurium (Ingrassia et al., 2005; Botes et al., 2008).

\subsection{Antitoxin effects}

The production of toxins is a significant factor responsible for the virulence of many pathogens. Certain probiotics can defend the host against toxins produced by pathogenic microorganisms (Nair et al., 2017). This defence can result from inhibition of toxin expression in pathogens. Real-time PCR confirmed that in vitro 15 different probiotic Lactobacillus strains inhibited Shiga toxin 2A expression via the production of organic acids at sub-bactericidal concentrations for enterohemorrhagic Escherichia coli (EHEC) O157: H7 (Carey et al., 2008).

Certain probiotics are even able to protect the host against cyanobacterial and fungal toxins. The basis of the observed protective effect is the rather physicochemical interaction between toxin and probiotic than metabolic inactivation. Deoxynivalenol is a mycotoxin that is a contaminant of cereal crops and can cause gastroenteritis. Lactobacillus rhamnosus GG dead or alive, can bind deoxynivalenol and, therefore, potentially restrict the bioavailability of this toxin (Turner et al., 2008). 
4 LAB with potential probiotic properties isolated from traditional fermented fish products

Traditional fermented fish products can be used as potential probiotics sources since they are dominated by a diverse variety of LAB (Ngasotter et al., 2020). Most of the LAB present in traditional fermented fish products are Lactobacillus species (Table 1). Other genera, including species of Streptococcus, Lactococcus, Weissella, Pediococcus, Leuconostoc, etc are also found (Table 1). Based on in vitro and in vivo studies, $\mathrm{LAB}$ isolated from traditional fermented fish products has promising characteristics as probiotic candidates (Table 2). In vitro assessment shows that many LAB isolated from traditional fish products tolerate bile salt and low $\mathrm{pH}$ environment and possess antagonistic activity against foodborne pathogens (Table 2). These characteristics are similar to those of intestinal microorganisms, such as $L$. acidophilus and $L$. casei that are commonly used as probiotics (Nuraida et al., 2014; Nuraida, 2015). Several studies suggest that the LAB in traditional fermented fish have adapted to environments that resemble the GI tract and hence, have potential as probiotic microorganisms.

Lactobacillus plantarum and Leuconostoc mesenteroides isolated from saba-narezushi (salted and fermented fish with rice), a traditional Japanese fish prepared from chub mackerel showed probiotic properties like the ability to grow in MRS media containing $3 \mathrm{~g} / \mathrm{L}$ bile and could also survive at low pH of 3.6 (Kanno et al., 2012). Similarly, L. plantarum (Lp-a205g, a206g, 5FM6, and 7FM10) and L. mesenteroides (Lnm-1RM3) isolated from sabanarezushi showed probiotic properties like survival at low $\mathrm{pH}$ and tolerance to bile. Moreover, L. mesenteroide (Lnm-1RM3) showed very high antimicrobial activity against $L$. monocytogenes invasion into Caco-2 cells. Further in-vivo study in mice model suggested that the invasion of L. monocytogenes tended to be suppressed by administering heat-killed Lnm-1RM3 cells with drinking water to the mice. These results suggest that live and heat-killed Lnm-1RM3 cell intake might prevent the entero-gastric invasion and infection of $L$. monocytogenes (Nakamura et al., 2012).

Pediococcus acidilactici (BksC24) isolated from Bakasang, an Indonesian traditional fermented fish product made from the guts of Katsuwonus pelamis, small fish, and fish eggs showed very high antimicrobial ability to inhibit the growth of pathogenic bacteria and spoilage bacteria. The indicator strains used in this study were $E$. coli, S.aureus, and Pseudomonas fluorescens (Lawalata et al., 2011).

Similarly, LAB (unidentified) species isolated from Bekasam showed antimicrobial activity against five indicator bacteria associated with foodborne diseases i.e E. coli, S. typhimurium, Bacillus cereus, S. aureus, and L. monocytogenes. The highest inhibition was against $S$. aureus. It was concluded that the inhibition activity of LAB from Indonesian bekasam was due to organic acids and they are probably the main preservative factor in the bekasam (Desnair, 2013).
Heat-killed L. paracasei (NFRI 7415) isolated from Japanese fermented fish (funa-sushi) inhibited mesangial proliferative glomerulonephritis by alcohol intake with stress in mice model (Yamada et al., 2018). Similarly, L. plantarum, Lactococcus lactis, and Pediococcus pentosaceus isolated from few traditional fermented fish from the Sanriku Satoumi region in Japan possessed immune-promoting and/or anti-inflammation properties. The isolates were resistant to low $\mathrm{pH}$ and bile. The strains also protected human enterocyte like HT-29 from $\mathrm{H}_{2} \mathrm{O}_{2}$ toxicity (Kuda et al., 2014). In another study, L. plantarum (JBCC105645 and JBCC105683) isolated from jeotgal, a traditional Korean salt fermented seafood, showed probiotic activity like in-vivo immune-stimulation, inhibition of atopic dermatitis-like skin lesions, and reduction serum IgE levels in mice model. Furthermore, the Lactobacillus strain induced macrophages to produce IL-12 in vitro (Park et al., 2017).

Lactobacillus spp. isolated from tungtap, a traditionally fermented fish (Puntius spp. or Danio spp.) of Meghalaya in Northeast India were found to possess many health-promoting probiotic properties, which included tolerance to acid and bile, cell surface hydrophobicity, cholesterol-lowering, and p-nitrophenyl-b-Dglucuronide activity, and also produced b-D-glucosidase enzyme. The majority of Lactobacillus isolates were antibiotic-sensitive and had strong antagonistic activity against certain indicator bacteria, adding to their probiotic nature (Rapsang \& Joshi, 2015). Similarly, L. coryniformis subsp. torquens $\mathrm{T} 2: \mathrm{L} 1$ (isolated from tungtap) showed antimicrobial activity against indicator strain Enterococcus faecium DSM 20477 while Bacillus subtilis T1:S1 (isolated from tungtap) against Streptococcus mutans DSM 6178 (Thapa et al., 2004). On the other hand, Lactococcus plantarum, L. fructosus, Enterococcus faecium, L. amylophilus, L. lactis subsp. cremoris, and L. coryniformis subsp. torquens isolated from ngari, hentak, and tungtap (traditional fermented fish products of Northeast India) showed a high degree of hydrophobicity among which L. fructosus HL1 (isolated from hentak) showed the highest percentage of hydrophobicity of $84.3 \%$. All other strains had more than $30 \%$ hydrophobicity (Thapa et al., 2004). In another study, E. faecium (BDU7) isolated from ngari, a traditional fermented fish of Manipur in Northeast India, showed acid and bile tolerance establishing a possibility of the isolate to be considered as a probiotic strain. The isolate also showed auto-aggregation and hydrophobicity of $72.7 \%$ and 54.8\%, respectively (Abdhul et al., 2014). Similarly, L. brevis strain LAP2, isolated from hentak (a fermented fish item of Manipur, India) showed a huge range of functional characteristics to be pondered as a significant probiotic candidate such as in-vitro survival at low $\mathrm{pH}$ conditions, tolerance to bile salt $(0.3 \% \mathrm{w} / \mathrm{v}$ sodium thioglycollate), good auto-aggregation, hydrophobicity and also a significant proteolytic activity. The isolate also exhibited antimicrobial activity against human pathogens. The antibiotic susceptibility pattern of the isolate showed its safe consumption without any health risk (Aarti et al., 2017). 
Table 1 Occurrence of lactic acid bacteria in some traditional fermented fish products

\begin{tabular}{|c|c|c|c|}
\hline Fermented fish product & Country & Lactic acid bacteria present & References \\
\hline Plaa-som & Thailand & $\begin{array}{c}\text { Streptococcus salivarius and Enterococcus faecalis } \\
\text { Lactococcus garvieae, Weissella cibaria, Pediococcus pentosaceus, Streptococcus bovis, Lb. plantarum and } \\
\text { Lb. fermentum }\end{array}$ & $\begin{array}{l}\text { Hwanhlem et al. (2011) } \\
\text { Kopermsub \& Yunchalard (2010) }\end{array}$ \\
\hline Som-fak & & $\begin{array}{c}\text { Leuconostoc spp., Lb. brevis, Lc. Lactis, Lb. curvatus, Lb. casei, Lb. pentosus and Lb. plantarum } \\
\text { Pediococcus sp. and Lactobacillus sp. }\end{array}$ & $\begin{array}{l}\text { Paludan-Müller et al. (1999) } \\
\text { Tanasupawat et al. (1993) }\end{array}$ \\
\hline Hoi-dorng & & $\begin{array}{l}\text { Lactobacillus sp., Lb. plantarum, Carnobacterium piscicola, and Lc. lactis } \\
\text { Lb. farciminis }\end{array}$ & $\begin{array}{l}\text { Østergaard et al. (1998) } \\
\text { Tanasupawat et al. (1998) }\end{array}$ \\
\hline Pla-ra & & Lb. farciminis, Leuconostoc sp., and other Lactobacillus sp. & Tanasupawat et al. (1998) \\
\hline Pla-chom & & Lb. pentosus, L. farciminis and other Lactobacillus sp. & Tanasupawat et al. (1998) \\
\hline Kung-chom & & $L b$. pentosus, $L b$. plantarum, and $L b$. farciminis & Tanasupawat et al. (1998) \\
\hline Bekasam & Indonesia & Unidentified LAB isolates & Desniar (2013) \\
\hline Rusip & & $\begin{array}{l}\text { Streptococcus sp., Lactobacillus sp. \& Leuconostoc sp. } \\
\text { Pediococcus } \mathrm{sp} . \\
\text { Leuconostoc } \mathrm{sp} ., \text { Streptococcus } \mathrm{sp} ., \text { and Lactococcus } \mathrm{sp} .\end{array}$ & $\begin{array}{l}\text { Dessi (1999) } \\
\text { Kusmarwati et al. (2014) } \\
\text { Yuliana et al. (2018) }\end{array}$ \\
\hline Chao & & Lb. plantarum, Lb. curvatus, $P$. pentosaceus, and $P$. acidilactici. & Matti et al. (2019) \\
\hline $\begin{array}{l}\text { Chouguiyu (Stinky Mandarin } \\
\text { fish) }\end{array}$ & China & $\begin{array}{c}\text { Lb. sakei, Lc. garvieae, Lc. raffinolactis, Lc. lactis, Vagococcus sp., Enterococcus hermanniensis, } \\
\text { Macrococcus caseolyticus and Streptococcus parauberis }\end{array}$ & Dai et al. (2013) \\
\hline $\begin{array}{l}\text { Traditional Fermented Sea- } \\
\text { fish }\end{array}$ & & Leuconostoc citreum, Lc. lactis, and Lb. pentosus & Zhu et al. (2016) \\
\hline Burong Bangus & Philippines & Streptococcus, Pediococcus, Lactobacillus, and Leuconostoc & Olympia et al. (1992) \\
\hline Burong isda & & Lb. plantarum & Olympia et al. (1995) \\
\hline Budu & Malaysia & Lb. casei, Lb. plantarum, and Lb. paracasei & Liasi et al. (2009) \\
\hline Pekasam & & Lb. plantarum and Lb. pentosus & Muryany et al. (2017) \\
\hline Ngari, Hentak, and Tungtap & India & $\begin{array}{c}\text { Enterococcus faecium, Lc. lactis, Lc. plantarum, Lb. fructosus, Lb. amylophilus, Lb. coryniformis subsp. } \\
\text { Torquens and Lb. plantarum }\end{array}$ & Thapa et al. (2004) \\
\hline
\end{tabular}

Journal of Experimental Biology and Agricultural Sciences

http://www.jebas.org 
Table 2 Characteristics and probiotic properties of some lactic acid bacteria isolated from traditional fermented fish products based on in vitro and in vivo studies

Lactic acid bacteria

Source of LAB

Characteristics and probiotic properties

Bile and acid tolerant

References

Kanno et al.

(2012)

Lactobacillus plantarum, Leuconostoc mesenteroides Saba-narezushi

Bile salt and low $\mathrm{pH}$ tolerant, high antimicrobial activity against $L$. monocytogenes, prevent the entero-

gastric invasion and infection of L. monocytogenes in rats

Nakamura et al.

$7 \mathrm{FM} 10$

Saba-narezushi

Leuconostoc mesenteroide (Lnm-1RM3)

Pediococcus acidilactici (BksC24)

Bakasang

Antimicrobial activity against Escherichia coli, Staphylococcus aureus, and Pseudomonas fluorescens (2011)

\begin{tabular}{|c|c|c|c|}
\hline Unidentified LAB species & Bekasam & $\begin{array}{c}\text { antimicrobial activity against Escherichia coli, Salmonella typhimurium, Bacillus cereus, } \\
\text { Staphylococcus aureus, and Listeria monocytogenes }\end{array}$ & Desnair (2013) \\
\hline Lb. paracasei (NFRI 7415) & Funa-sushi & Inhibited mesangial proliferative glomerulonephritis by alcohol intake with stress in rats & $\begin{array}{l}\text { Yamada et al. } \\
\text { (2018) }\end{array}$ \\
\hline Lb. plantarum, Lc. lactis, P. pentosaceus & $\begin{array}{l}\text { Japanese traditional } \\
\text { fermented fish }\end{array}$ & $\begin{array}{l}\text { Bile salt and low pH tolerant, anti-inflammation properties, protected human enterocyte like HT-29 } \\
\text { from } \mathrm{H}_{2} \mathrm{O}_{2} \text { toxicity }\end{array}$ & Kuda et al. (2014) \\
\hline Lb. plantarum (JBCC105645 and JBCC105683) & Jeotgal & $\begin{array}{l}\text { In vivo immunostimulation, inhibition of atopic dermatitis-like skin lesions, and reduction serum IgE } \\
\text { levels in rats; stimulated macrophages to produce IL-12 in vitro }\end{array}$ & Park et al. (2017) \\
\hline Lactobacillus spp. & Tungtap & $\begin{array}{l}\text { Tolerance to acid and bile, cell surface hydrophobicity, antibiotic sensitivity, antimicrobial activity, } \\
\text { cholesterol-lowering, p-nitrophenyl-b-D-glucuronide activity and b-D-glucosidase activity }\end{array}$ & $\begin{array}{l}\text { Rapsang and Joshi } \\
\text { (2015) }\end{array}$ \\
\hline Lb. coryniformis subsp. torquens $\mathrm{T} 2: \mathrm{L} 1$ & Tungtap & Antimicrobial activity against indicator strain Enterococcus faecium DSM 20477 & $\begin{array}{l}\text { Abdhul et al. } \\
\text { (2014) }\end{array}$ \\
\hline $\begin{array}{l}\text { Lc. plantarum, Lb. fructosus, Lb. amylophilus, } \\
\text { Enterococcus faecium, Lb coryniformis subsp. } \\
\text { Torquens, and Lc. lactis subsp. Cremoris }\end{array}$ & $\begin{array}{l}\text { Ngari, Hentak, and } \\
\text { Tungtap }\end{array}$ & Acid and bile tolerance \& good adhesion properties & $\begin{array}{l}\text { Abdhul et al. } \\
\text { (2014) }\end{array}$ \\
\hline Lb. brevis (LAP2) & Hentak & $\begin{array}{c}\text { Bile salt and low pH tolerant, good adhesion properties, proteolytic activity, against human pathogens } \\
\text { and antibiotic susceptibility }\end{array}$ & Aarti et al. (2017) \\
\hline Lb. plantarum, Lb. pentosus & Pekasam & $\begin{array}{l}\text { Bile salt and low pH tolerant, antimicrobial activity against Escherichia coli, Staphylococcus aureus } \\
\text { and Klebsiella sp., \& antibiotic sensitivity }\end{array}$ & $\begin{array}{l}\text { Muryany et al. } \\
\text { (2017) }\end{array}$ \\
\hline $\begin{array}{l}\text { Leuconostoc citreum ATCC 49370(T) (AF111948), } \\
\text { Lc. lactis subsp. lactis NCDO 604 (T) (AB100803), } \\
\text { Lb. pentosus JCM 1558(T) (D79211) }\end{array}$ & $\begin{array}{l}\text { Traditional Chinese } \\
\text { fermented fish }\end{array}$ & Antibacterial activity against Staphylococcus aureus, Escherichia coli and Vibrio parahaemolyticus & Zhu et al. (2016) \\
\hline $\begin{array}{l}\text { Lb. casei LA17, Lb. plantarum (LA22), Lb. } \\
\text { paracasei (LA02) }\end{array}$ & Budu & Antimicrobial activity \& antibiotic susceptibility & Liasi et al. (2009) \\
\hline
\end{tabular}

Journal of Experimental Biology and Agricultural Sciences

http://www.jebas.org 
Lactobacillus plantarum and $L$. pentosus isolated from a Malaysian traditional fermented fish (Pekasam) exhibited potential probiotic properties to be developed as biotherapeutic agents. The isolates showed antagonism activities against the common pathogenic bacteria; E. coli, S. aureus, and Klebsiella sp. and were tolerant of various $\mathrm{pH}(3.0,5.0$, and 7.5$)$ and $0.3 \%(\mathrm{w} / \mathrm{v})$ bile salts. The strains were also susceptible to various antibiotics tested (Muryany et al., 2017). In another study, three strains of LAB; Leuconostoc citreum ATCC 49370(T) (AF111948), Lactococcus lactis subsp. lactis NCDO 604(T) (AB100803) and Lactobacillus pentosus JCM 1558(T) (D79211) isolated from traditional Chinese fermented fish exhibited a good antibacterial activity and strongly inhibited the growth of $S$. aureus, E. coli, and Vibrio parahaemolyticus and improved the organoleptic properties of fermented fish (Zhu et al., 2016). Similarly, Lactobacillus casei (LA17), Lactobacillus plantarum (LA22), and Lactobacillus paracasei (LA02) were isolated from Malaysian fermented fish product, Budu exhibited antimicrobial activity against a range of Gram-positive and Gram-negative microorganisms. The strains also showed antibiotic susceptibility to a wide range of antibiotics used in the study (Liasi et al., 2009).

\section{Conclusion}

$\mathrm{LAB}$ are the dominant microorganisms in most of the fermented foods, especially in traditional fermented fish products. These LAB strains isolated from the traditional fermented fish products have promising probiotic properties as shown by several in vitro and in vivo studies. Although most of the studies have shown that $\mathrm{LAB}$ isolated from traditional fermented fish products has promising characteristics as probiotic candidates due to their probiotic properties. These studies are mainly preliminary and need to be confirmed in animal and human studies. Moreover, the exploration of potentially beneficial microorganisms in traditional fermented fish products needs to be extended to microorganisms other than $\mathrm{LAB}$ that are also present in them. For example, yeasts and some species of Bacillus are potential microorganisms for probiotics.

\section{Author contributions}

All the authors substantially contributed to the conception, compilation of data, checking and approving the final version of the manuscript, and agree to be accountable for its contents.

\section{Acknowledgments}

All the authors acknowledge and thank their respective Institutes and Universities.

\section{Conflict of interest}

All authors declare that there exist no commercial or financial relationships that could, in any way, lead to a potential conflict of interest.

\section{Funding}

This compilation is a review article written by its authors and required no substantial funding to be stated.

\section{References}

Aarti C, Khusro A, Varghese R, Arasu MV, Agastian P, Al-Dhabi NA, Choi KC (2017) In vitro studies on probiotic and antioxidant properties of Lactobacillus brevis strain LAP2 isolated from Hentak, a fermented fish product of North-East India. LWT 86: 438-446.

Abdhul K, Ganesh M, Shanmughapriya S, Kanagavel M, Anbarasu K, Natarajaseenivasan K (2014) Antioxidant activity of exopolysaccharide from probiotic strain Enterococcus faecium (BDU7) from Ngari. International Journal of Biological Macromolecules 70: 450-454.

Adams M (2009) Fermented fish. In: Fernandes R (Ed). Microbiology handbook fish and seafood, Leatherhead Publishing, United Kingdom, 123-140.

Adimpong DB, Nielsen DS, Sørensen KI, Derkx PM, Jespersen L (2012) Genotypic characterization and safety assessment of lactic acid bacteria from indigenous African fermented food products. BMC Microbiology 12(1): 75-86.

Bell V, Ferrão J, Pimentel L, Pintado M, Fernandes T (2018) One health, fermented foods, and gut microbiota. Foods 7(12): 195.

Boke H, Aslim B, Alp G (2010) The role of resistance to bile salts and acid tolerance of exopolysaccharides (EPSS) produced by yogurt starter bacteria. Archives of Biological Sciences 62(2): 323328.

Booijink CC, Zoetendal EG, Kleerebezem M, De Vos WM (2007) Microbial communities in the human small intestine: coupling diversity to metagenomics. Future Microbiology 2(3): 285-295.

Botes M, Loos B, van Reenen CA, Dicks LM (2008) Adhesion of the probiotic strains Enterococcus mundtii ST4SA and Lactobacillus plantarum 423 to Caco-2 cells under conditions simulating the intestinal tract, and in the presence of antibiotics and anti-inflammatory medicaments. Archives of Microbiology 190(5): 573-584.

Bubnov RV, Babenko LP, Lazarenko LM, Mokrozub VV, Spivak MY (2018) Specific properties of probiotic strains: relevance and benefits for the host. EPMA Journal 9(2): 205-223.

Carey CM, Kostrzynska M, Ojha S, Thompson S (2008) The effect of probiotics and organic acids on Shiga-toxin 2 gene expression in 
enterohemorrhagic Escherichia coli O157: H7. Journal of Microbiological Methods 73(2): 125-132.

Chugh B, Kamal-Eldin A (2020) Bioactive compounds produced by probiotics in food products. Current Opinion in Food Science 32: $76-82$.

Cleusix V, Lacroix C, Vollenweider S, Le Blay G (2008) Glycerol induces reuterin production and decreases Escherichia coli population in an in vitro model of colonic fermentation with immobilized human feces. FEMS Microbiology Ecology 63(1): 56-64.

Collado MC, Meriluoto J, Salminen S (2007) Measurement of aggregation properties between probiotics and pathogens: in vitro evaluation of different methods. Journal of Microbiological Methods 71(1): 71-74.

Collado MC, Meriluoto J, Salminen S (2008) Adhesion and aggregation properties of probiotic and pathogen strains. European Food Research and Technology 226(5): 1065-1073.

Dai Z, Li Y, Wu J, Zhao Q (2013) Diversity of lactic acid bacteria during fermentation of a traditional Chinese fish product, Chouguiyu (stinky mandarinfish). Journal of Food Science 78(11): M1778-M1783.

Desniar M (2013) Characterization of lactic acid bacteria isolated from an Indonesian fermented fish (bekasam) and their antimicrobial activity against pathogenic bacteria. Emirates Journal of Food and Agriculture 25(6): 489-494.

Dessi (1999) Sifat Kimiawi dan Ciri-ciriBakteri Pada Rusip Yang DibuatDenganBerbagaiSumber Karbon. Skripsi, Universitas Sriwijaya, Indralaya.

Didari T, Solki S, Mozaffari S, Nikfar S, Abdollahi M (2014) A systematic review of the safety of probiotics. Expert Opinion on Drug Safety 13(2): 227-239.

Dlamini ZC, Langa RL, Aiyegoro OA, Okoh AI (2019) Safety evaluation and colonisation abilities of four lactic acid bacteria as future probiotics. Probiotics and Antimicrobial Proteins 11(2): 397-402.

Donlon B, Colleran E (1993) A comparison of different methods to determine the hydrophobicity of acetogenic bacteria. Journal of Microbiological Methods 17(1): 27-37.

Doyle RJ, Rosenberg M (1990) Microbial cell surface hydrophobicity. American Society for Microbiology, Washington DC, 425.
Duary RK, Rajput YS, Batish VK, Grover S (2011) Assessing the adhesion of putative indigenous probiotic lactobacilli to human colonic epithelial cells. Indian Journal of Medical Research 134(5): 664-671.

Elli M, Zink R, Rytz A, Reniero R, Morelli L (2000) Iron requirement of Lactobacillus spp. in completely chemically defined growth media. Journal of Applied Microbiology 88(4): 695-703.

FAO/WHO (2002) Guidelines for the Evaluation of Probiotics in Food. FAO/WHO, London.

Foligne B, Daniel C, Pot B (2013) Probiotics from research to market: the possibilities, risks and challenges. Current Opinion in Microbiology 16(3): 284-292.

Fuller R (1989) A review: probiotics in man and animals. Journal of Applied Microbiology 66(5): 365-378.

Gómez NC, Ramiro JM, Quecan BX, de Melo Franco BD (2016) Use of potential probiotic lactic acid bacteria (LAB) biofilms for the control of Listeria monocytogenes, Salmonella typhimurium, and Escherichia coli O157: H7 biofilms formation. Frontiers in Microbiology 7: 863.

Grill JP, Cayuela C, Antoinev JM, Schneider F (2000) Isolation and characterization of a Lactobacillus amylovorus mutant depleted in conjugated bile salt hydrolase activity: relation between activity and bile salt resistance. Journal of Applied Microbiology 89(4): 553-563.

Gunn JS (2000) Mechanisms of bacterial resistance and response to bile. Microbes and Infection 2(8): 907-913.

Haghshenas B, Abdullah N, Nami Y, Radiah D, Rosli R, Khosroushahi AY (2014) Different effects of two newly-isolated probiotic Lactobacillus plantarum $15 \mathrm{HN}$ and Lactococcus lactis subsp. Lactis 44Lac strains from traditional dairy products on cancer cell lines. Anaerobe 30: 51-59.

Helland MH, Wicklund T, Narvhus JA (2004) Growth and metabolism of selected strains of probiotic bacteria, in maize porridge with added malted barley. International Journal of Food Microbiology 91(3): 305-313.

Hernández-Gómez JG, López-Bonilla A, Trejo-Tapia G, ÁvilaReyes SV, Jiménez-Aparicio AR, Hernández-Sánchez H (2021) In Vitro Bile Salt Hydrolase (BSH) Activity Screening of Different Probiotic Microorganisms. Foods 10(3): 674.

Herreros MA, Sandoval H, González L, Castro JM, Fresno JM, Tornadijo ME (2005) Antimicrobial activity and antibiotic resistance of lactic acid bacteria isolated from Armada cheese (a Spanish goats' milk cheese). Food Microbiology 22(5): 455-459.

Journal of Experimental Biology and Agricultural Sciences http://www.jebas.org 
Horackova S, Vesela K, Klojdova I, Bercikova M, Plockova M (2020) Bile salt hydrolase activity, growth characteristics and surface properties in Lactobacillus acidophilus. European Food Research and Technology 246: 1627-1636.

Hwanhlem N, Buradaleng S, Wattanachant S, Benjakul S, Tani A, Maneerat S (2011) Isolation and screening of lactic acid bacteria from Thai traditional fermented fish (Plasom) and production of Plasom from selected strains. Food Control 22(3-4): 401-407.

Ingrassia I, Leplingard A, Darfeuille-Michaud A (2005) Lactobacillus casei DN-114 001 inhibits the ability of adherentinvasive Escherichia coli isolated from Crohn's disease patients to adhere to and to invade intestinal epithelial cells. Applied and Environmental Microbiology 71(6): 2880-2887.

Ishimwe N, Daliri EB, Lee BH, Fang F, Du G (2015) The perspective on cholesterol-lowering mechanisms of probiotics. Molecular Nutrition \& Food Research 59(1): 94-105.

Janković T, Frece J, Abram M, Gobin I (2012) Aggregation ability of potential probiotic Lactobacillus plantarum strains. International Journal of Sanitary Engineering Research 6(1): 19-24

Kanno T, Kuda T, An C, Takahashi H, Kimura B (2012) Radical scavenging capacities of saba-narezushi, Japanese fermented chub mackerel, and its lactic acid bacteria. LWT - Food Science and Technology 47(1): 25-30.

Kopermsub P, Yunchalard S (2010) Identification of lactic acid bacteria associated with the production of plaa-som, a traditional fermented fish product of Thailand. International Journal of Food Microbiology 138(3): 200-204.

Kose S, Hall GM (2011) Sustainability of fermented fishproducts. In: Hall GM (Ed.) Fish processing: Sustainability and new opportunities, Pp. 138-166.

Kotzamanidis C, Kourelis A, Litopoulou-Tzanetaki E, Tzanetakis N, Yiangou M (2010) Evaluation of adhesion capacity, cell surface traits and immunomodulatory activity of presumptive probiotic Lactobacillus strains. International Journal of Food Microbiology 140(2-3): 154-163.

Krausova G, Hyrslova I, Hynstova I (2019) In vitro evaluation of adhesion capacity, hydrophobicity, and auto-aggregation of newly isolated potential probiotic strains. Fermentation 5(4): 100.

Kuda T, Kawahara M, Nemoto M, Takahashi H, Kimura B (2014) In vitro antioxidant and anti-inflammation properties of lactic acid bacteria isolated from fish intestines and fermented fish from the
Sanriku Satoumi region in Japan. Food Research International 64: 248-255.

Kusmarwati A, Arief FR, Haryati S (2014) Exploration of Bacteriocin from lactic acid bacteria origin from Bangkanese and Kalimantanese rusip. JPB Perikanan 9(1): 29-40.

La Fata G, Weber P, Mohajeri MH (2018) Probiotics and the gut immune system: indirect regulation. Probiotics and antimicrobial proteins 10(1): 11-21.

Lawalata HJ, Sembiring L, Rahayu ES (2011) Molecular Identification of Lactic Acid Bacteria Producing Antimicrobial Agents from Bakasang, An Indonesian Traditional Fermented Fish Product. Indonesian Journal of Biotechnology 16(2): 93-99.

Liasi SA, Azmi TI, Hassan MD, Shuhaimi M, Rosfarizan M, Ariff AB (2009) Antimicrobial activity and antibiotic sensitivity of three isolates of lactic acid bacteria from fermented fish product, Budu. Malaysian Journal of Microbiology 5(1): 33-37.

Malik A, Sakamoto M, Hanazaki S, Osawa M, Suzuki T, Tochigi M, Kakii K (2003) Coaggregation among nonflocculating bacteria isolated from activated sludge. Applied and Environmental Microbiology 69(10): 6056-6063.

Maqueda M, Sánchez-Hidalgo M, Fernández M, Montalbán-López M, Valdivia E, Martínez-Bueno M (2008) Genetic features of circular bacteriocins produced by Gram-positive bacteria. FEMS Microbiology Reviews 32(1): 2-22.

Martín R, Olivares M, Marín ML, Fernández L, Xaus J, Rodríguez JM (2005) Probiotic potential of 3 lactobacilli strains isolated from breast milk. Journal of Human Lactation 21(1): 8-17.

Mathur H, Beresford TP, Cotter PD (2020) Health benefits of lactic acid bacteria (LAB) fermentates. Nutrients 12(6): 1679.

Matti A, Utami T, Hidayat C, S Rahayu E (2019) Isolation, Screening, and Identification of Proteolytic Lactic Acid Bacteria from Indigenous Chao Product. Journal of Aquatic Food Product Technology 28(7): 781-793.

Mbye M, Baig MA, AbuQamar SF, El-Tarabily KA, Obaid RS, Osaili TM, Al-Nabulsi AA, Turner MS, Shah NP, Ayyash MM (2020) Updates on understanding of probiotic lactic acid bacteria responses to environmental stresses and highlights on proteomic analyses. Comprehensive Reviews in Food Science and Food Safety 19(3): 1110-1124.

Mekonnen SA, Merenstein D, Fraser CM, Marco ML (2020) Molecular mechanisms of probiotic prevention of antibioticassociated diarrhea. Current Opinion in Biotechnology 61: 226234. 
Monteagudo-Mera A, Rastall RA, Gibson GR, Charalampopoulos D, Chatzifragkou A (2019) Adhesion mechanisms mediated by probiotics and prebiotics and their potential impact on human health. Applied Microbiology and Biotechnology 103(16): $6463-$ 6472.

Mulaw G, SisayTessema T, Muleta D, Tesfaye A (2019) In vitro evaluation of probiotic properties of lactic acid bacteria isolated from some traditionally fermented Ethiopian food products. International Journal of Microbiology 2019: 7179514.

Muryany IM, Salwany IM, Ghazali AR, Hing HL, Fadilah NR (2017) Identification and characterization of the Lactic Acid Bacteria isolated from Malaysian fermented fish (Pekasam). International Food Research Journal 24(2): 868-875.

Nair MS, Amalaradjou MA, Venkitanarayanan K (2017) Antivirulence properties of probiotics in combating microbial pathogenesis. Advances in Applied Microbiology 98: 1-29.

Nakamura S, Kuda T, An C, Kanno T, Takahashi H, Kimura B (2012) Inhibitory effects of Leuconostoc mesenteroides 1RM3 isolated from narezushi, a fermented fish with rice, on Listeria monocytogenes infection to Caco-2 cells and $\mathrm{A} / \mathrm{J}$ mice. Anaerobe 18(1): 19-24.

Ngasotter S, Waikhom D, Mukherjee S, Devi MS, Singh AS (2020) Diversity of Lactic Acid Bacteria (LAB) in Fermented Fish Products: A Review. International Journal of Current Microbiology and Applied Sciences 9(05): 2238-2249.

Nikolic M, Jovcic B, Kojic M, Topisirovic L (2010) Surface properties of Lactobacillus and Leuconostoc isolates from homemade cheeses showing auto-aggregation ability. European Food Research and Technology 231(6): 925-931.

Nuraida L (2015) A review: Health promoting lactic acid bacteria in traditional Indonesian fermented foods. Food Science and Human Wellness 4(2): 47-55.

Nuraida L, Owens JD, Bakar JA, Kuswanto KR (2014) Lactic Vegetable and Fruit Fermentations. In: Owen JD (Ed). Indigenous Fermented Foods of Southeast Asia, CRC Press, 185-209.

Oelschlaeger TA (2010) Mechanisms of probiotic actions-a review. International Journal of Medical Microbiology 300(1): $57-$ 62.

Olympia M, Fukuda H, Ono H, Kaneko Y, Takano M (1995) Characterization of starch-hydrolyzing lactic acid bacteria isolated from a fermented fish and rice food, "BurongIsda", and its amylolytic enzyme. Journal of Fermentation and Bioengineering 80(2): 124-130.
Olympia M, Ono H, Shinmyo A, Takano M (1992) Lactic acid bacteria in fermented fishery product, "burongbangus". Journal of Fermentation and Bioengineering 73(3): 193-197.

Østergaard A, Embarek PKB, Wedell-Neergaard C, Huss HH, Gram L (1998) Characterization of anti-listerial lactic acid bacteria isolated from Thai fermented fish products. Food Microbiology 15(2): 223-233.

Paludan-Müller C, Huss HH, Gram L (1999) Characterization of lactic acid bacteria isolated from a Thai low-salt fermented fish product and the role of garlic as substrate for fermentation. International Journal of Food Microbiology 46(3): 219-229.

Park MS, Song NE, Baik SH, Pae HO, Park SH (2017) Oral administration of lactobacilli isolated from Jeotgal, a salted fermented seafood, inhibits the development of 2 , 4-dinitrofluorobenzene-induced atopic dermatitis in mice. Experimental and Therapeutic Medicine 14(1): 635-641.

Parvez S, Malik KA, Ah Kang S, Kim HY (2006) Probiotics and their fermented food products are beneficial for health. Journal of Applied Microbiology 100(6): 1171-1185.

Patel AK, Singhania RR, Pandey A, Chincholkar SB (2010) Probiotic bile salt hydrolase: current developments and perspectives. Applied Biochemistry and Biotechnology 162(1): 166-180.

Piqué N, Berlanga M, Miñana-Galbis D (2019) Health benefits of heat-killed (Tyndallized) probiotics: An overview. International Journal of Molecular Sciences 20(10): 2534.

Prete R, Long SL, Gallardo AL, Gahan CG, Corsetti A, Joyce SA (2020) Beneficial bile acid metabolism from Lactobacillus plantarum of food origin. Scientific Reports 10(1): 1-11.

Rapsang GF, Joshi SR (2015) Molecular and probiotic functional characterization of Lactobacillus spp. associated with traditionally fermented fish, Tungtap of Meghalaya in northeast India. Proceedings of the National Academy of Sciences, India Section B: Biological Sciences 85(4): 923-933.

Reis JA, Paula AT, Casarotti SN, Penna ALB (2012) Lactic acid bacteria antimicrobial compounds: characteristics and applications. Food Engineering Reviews 4(2): 124-140.

Ren D, Zhu J, Gong S, Liu H, Yu H (2018) Antimicrobial characteristics of lactic acid bacteria isolated from homemade fermented foods. BioMed Research International 2018:5416725 .

Sassone-Corsi M, Nuccio SP, Liu H, Hernandez D, Vu CT, Takahashi AA, Edwards RA, Raffatellu M (2016) Microcins 
mediate competition among Enterobacteriaceae in the inflamed gut. Nature 540(7632): 280-283.

Singh SS, De Mandal S, Lalnunmawii E, Kumar NS (2018) Antimicrobial, antioxidant and probiotics characterization of dominant bacterial isolates from traditional fermented fish of Manipur, North-East India. Journal of Food Science and Technology 55(5): 1870-1879.

Solieri L, Bianchi A, Mottolese G, Lemmetti F, Giudici P (2014) Tailoring the probiotic potential of non-starter Lactobacillus strains from ripened Parmigiano Reggiano cheese by in vitro screening and principal component analysis. Food Microbiology 38: 240-249.

Spelhaug SR, Harlander SK (1989) Inhibition of foodborne bacterial pathogens by bacteriocins from Lactococcus lactis and Pediococcus pentosaceous. Journal of Food Protection 52(12): 856-862.

Succi M, Tremonte P, Reale A, Sorrentino E, Grazia L, Pacifico S, Coppola R (2005) Bile salt and acid tolerance of Lactobacillus rhamnosus strains isolated from Parmigiano Reggiano cheese. FEMS Microbiology Letters 244(1): 129-137.

Tanasupawat S, Okada S, Komagata K (1998) Lactic acid bacteria found in fermented fish in Thailand. Journal of General and Applied Microbiology 44(3): 193-200.

Tanasupawat S, Okada S, Suzuki K, Kozaki M, Komagata K (1993) Lactic acid bacteria, particularly heterofermentative lactobacilli, found in fermented foods in Thailand. Bulletin of the Japan Federation for Culture Collections 9: 65-78.

Thapa N, Pal J, Tamang JP (2004) Microbial diversity in ngari, hentak and tungtap, fermented fish products of North-East India. World Journal of Microbiology and Biotechnology 20(6): 599-607.

Turner PC, Wu QK, Piekkola S, Gratz S, Mykkänen H, El-Nezami H (2008) Lactobacillus rhamnosus strain GG restores alkaline phosphatase activity in differentiating Caco-2 cells dosed with the potent mycotoxin deoxynivalenol. Food and Chemical Toxicology 46(6): 2118-2123.

Urdaneta V, Casadesús J (2017) Interactions between bacteria and bile salts in the gastrointestinal and hepatobiliary tracts. Frontiers in Medicine 4: 163.

Verraes C, Van Boxstael S, Van Meervenne E, Van Coillie E, Butaye P, Catry B, De Schaetzen MA, Van Huffel X, Imberechts H, Dierick K, Daube G (2013) Antimicrobial resistance in the food chain: a review. International Journal of Environmental Research and Public Health 10(7): 2643-2669.

Wang LQ, Meng XC, Zhang BR, Wang Y, Shang YL (2010) Influence of cell surface properties on adhesion ability of bifidobacteria. World Journal of Microbiology and Biotechnology 26(11): 1999-2007

Wang C, Cui Y, Qu X (2018) Mechanisms and improvement of acid resistance in lactic acid bacteria. Archives of Microbiology 200(2): 195-201.

Weinberg ED (1997) The Lactobacillus anomaly: total iron abstinence. Perspectives in Biology and Medicine 40(4): 578-583.

Yamada Y, Endou M, Morikawa S, Shima J, Komatshzaki N (2018) Lactic acid bacteria isolated from Japanese fermented fish (funa-sushi) inhibit mesangial proliferative glomerulonephritis by alcohol intake with stress. Journal of Nutrition and Metabolism 2018: 6491907

Yuliana N, Koesoemawardani D, Susilawati S (2018) Lactic acid bacteria during fish fermentation (rusip). MOJ Food Processing \& Technology 6(2): 211-216.

Zhu WJ, Zhang XM, Ren WB, Sun LJ, Wang YL, Liu Y (2016) Isolation, Identification and Application of Lactic Acid Bacteria from Chinese Traditional Fermented Sea-fish. Medicine and Biopharmaceutical: Proceedings of the 2015 International Conference, 1506-1514. 